\title{
Spatio-Temporal Variations of Land-Cover Types in Osho Forest Reserve, Southwestern Nigeria
}

\author{
Olufunke Olubusayo Olayode \\ Department of Forest Resources and Wildlife Management, Ekiti State University, Ado-Ekiti, Nigeria
}

\section{Email address:}

olufunke.olayode@eksu.edu.ng

\section{To cite this article:}

Olufunke Olubusayo Olayode. Spatio-Temporal Variations of Land-Cover Types in Osho Forest Reserve, Southwestern Nigeria. American Journal of Agriculture and Forestry. Vol. 7, No. 5, 2019, pp. 168-176. doi: 10.11648/j.ajaf.20190705.12

Received: June 24, 2019; Accepted: July 23, 2019; Published: August 28, 2019

\begin{abstract}
The extent of any forest determines its capacity to supply goods and services which are indispensable for man's continued existence. However, increasing population of humans subjects forest under pressure to meet basic needs of man thereby modifying its extent mostly through deforestation and forest degradation. It therefore became necessary to investigate the extent of Osho Forest Reserve, Nigeria (longitudes $3^{\circ} 25^{\prime}$ and $5^{\circ} 00^{\prime} \mathrm{E}$, latitudes $7^{\circ} 00^{\prime}$ and $7^{\circ} 45^{\prime} \mathrm{N}$ ) with the use of Landsat imageries of 1984, 2000 and 2006. The imageries were georeferenced to the same coordinate system using topographical map of the study area. Bands 2, 4 and 5 were used since they are suitable for vegetation studies. Idrisi32 and ArcGIS 8.1 were used for the analyses and map production respectively. A supervised classification theme of Natural Forest (NF), Plantation and Farmland was adopted after reconnaissance survey in the study area. NF which covered $93.8 \%$ in 1984 shrank to $4.0 \%$ in 2006 , Plantation had occupied $6.0 \%$ in 1984 but increased to $9.0 \%$ in 2006 while Farmland significantly increased from $0.2 \%$ in 1984 to $87.0 \%$ within the same period. Although Plantation and Farmland increased over the study period, the declining NF extent has grave implications on the abilityof this forest ecosystem to sustainably deliver its benefits.
\end{abstract}

Keywords: Deforestation, Land-cover, Declining Natural Forest, Net Changes

\section{Introduction}

Tropical forest is a repository of diverse species of plants and animals which form a rich source of different goods and services being used globally. However, inspite of the various benefits derivable from the forests, the capacity of the ecosystem to produce is being hampered daily as a result of destructive human activities with attendant negative consequences. Stated more succinctly, tropical deforestation and degradation of forests in many parts of the world negatively affect the availability of forest goods and services. There is a growing concern about the destruction of the world's forests and in particular tropical forest partly because it harbours vast resources of plants and animals and also because of the crucial role it could play in mitigating the effects of climate change. Moreover, the highest rate of forest loss is said to be occurring in Africa [1]. This loss has three consequences. The first is that of lost biomass and tangible resources of immediate value otherwise known as goods and services. Secondly, there is impaired ecological processes such as catchment and carbon sequestration capacity of such forests while the third consequence is that of loss of biological diversity as communities, species and genes [2]. Specific site studies show that both forest and biodiversity loss are widespread however, data on rates and causes of such loss are grossly inadequate especially in a developing country like Nigeria. Nigeria is said to have the world's highest deforestation rate of primary forests because it lost $55.7 \%$ of its primary forests between 2000 and 2005 [3].

There is an urgent need to stop forest disappearance but for this to be a reality, the fact that deforestation and forest degradation are actually occurring must be acknowledged and this can be achieved by conducting land-cover change studies in vulnerable areas. Although, people generally concur to the usefulness of any forest yet most forest estates in the developing countries are not inventoried and where this is done, there is poor documentation of such data thereby frustrating inventory efforts. Cottorone [4] 
stated that forest statistics in Ethiopia are unreliable with no historical or contemporary forest records leading to little clarity in forestry data thus creating confusion for those involved in the sector and this has resulted in lack of attention by policy makers. The situation in Ethiopia is very similar to that of Nigeria in that historical and contemporary forest records are almost unavailable and where available, they are highly unreliable. This is consequent mainly upon very poor record keeping that permeates the management of various forest reserves in Nigeria.

The global climate system is affected by land-use and land-cover change through bio-geophysical, biogeochemical and energy exchange processes. These in turn affect climate at local, regional and global scales. The terrestrial albedo is often altered by use and this is the reason why climate change has been attributed to land-use. Knowledge about land-use and land-cover has become increasingly important as nations plan to overcome the problems of haphazard uncontrolled development, deteriorating environmental quality, loss of prime agricultural lands, destruction of important wetlands and loss of fish and wildlife habitat. Although land-use data have now received much attention than ever before, their importance have long been recognized considering the observation of [5] that land-use data are needed in the analysis of environmental processes and problems that must be understood if living conditions and standards are to be improved or maintained at current levels.

Concepts concerning land-cover and land-use are closely related and in many cases the two terms have been used interchangeably. The purposes for which lands are being used have associated types of cover, whether they be forest, agriculture, residence or industry. Nevertheless, some activities of man cannot be directly related to a specific type of land-cover and an example is hunting which is a very common pervasive recreational and in fact occupational use of land in Nigeria but it usually occurs on land that would be classified as some type of forest, range or agricultural land either during ground survey or image interpretation. Attributing hunting to a particular type of land-cover would be relative since it can relate to many cover types such as forests be it natural or artificial and farmlands. Although the land-cover will determine the species of animals present because species of animals are associated with cover types; in other words, habitat types determine animal types.

Classification of land is another phenomenon that can generate some controversies however, land classification according to [6] depends on the objective of the study and the prevalent land-uses previously gathered through reconnaissance survey. There are different perspectives in the classification process and the process itself tends to be subjective even when an objective numerical approach is used. There is in fact no logical reason to expect that one detailed inventory should be adequate for more than a short time since land-use and land-cover patterns change in keeping with demands for natural resources [5]. Eventually the categorized land-cover is based on the activity recorded directly by the image-forming devices in remote sensing.

Forest cover change knowledge is often derived from two main sources. The first is from expertise of forest practitioners while the second is from results of research studies [7]. The knowledge of forest practitioners is mainly generated through extensive practical experience but generally is less well documented and quantitative [8]. This may be due to the fact that individual experiences are constrained by the scale and time frame of personal observations [9].

Expert knowledge may be best suited for understanding local forest cover changes while its applicability beyond local scales is uncertain [10]. In contrast, knowledge of forest cover changes resulting from research studies is mostly explicitly documented and quantitative. Depending on the scale and design of studies, this knowledge may be valuable for understanding local or larger scale forest cover change [11]. Results of research studies and expert knowledge from forest managers need not be isolated from each other rather they should be complementary. Nevertheless, it has been discovered that resource management practitioners do not make much use of literature to supplement or evaluate experiential knowledge [12]. This study therefore examines spatiotemporal variation of land-cover in Osho Forest Reserve using landsat imageries as well as projection of future land-cover and their impacts.

\section{Materials and Methods}

\subsection{Description of the Study Area}

Osho Forest Reserve (FR) is located in Ido Local Government Area of Oyo State, South-western Nigeria. It is situated between latitudes $7^{\circ} 00^{\prime}$ and $7^{\circ} 45^{\prime} \mathrm{N}$, and longitudes $3^{\circ} 25^{\prime}$ and $5^{\circ} 00^{\prime} \mathrm{E}$ in the derived savanna ecological zone. Figures 1, 2 and 3 show the location maps of Osho FR in relation to Africa. The Forest Reserve which had an original land area of about 5,180hectares had been reduced to 3,500 hectares by an amendment order. The Forest Reserve used to harbor an abundance of valuable trees and other flora as well as fauna species. The reserve has an estimated altitude of $152 \mathrm{~m}$ above the sea level. The highest minimum temperature recorded is $23.88^{\circ} \mathrm{C}$ while that of maximum temperature is $31.85^{\circ} \mathrm{C}$. Also, the highest rainfall recorded is $180.15 \mathrm{~mm}$. 


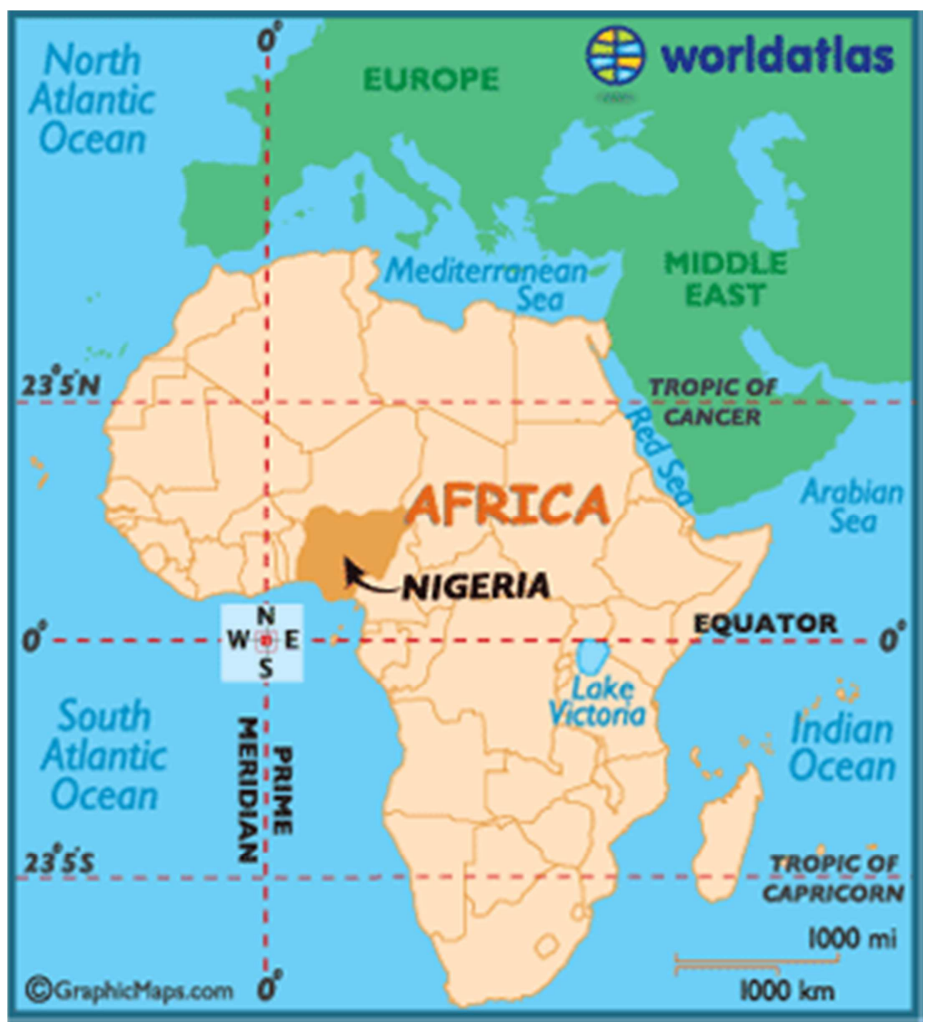

Figure 1. Map of Africa showing Nigeria.

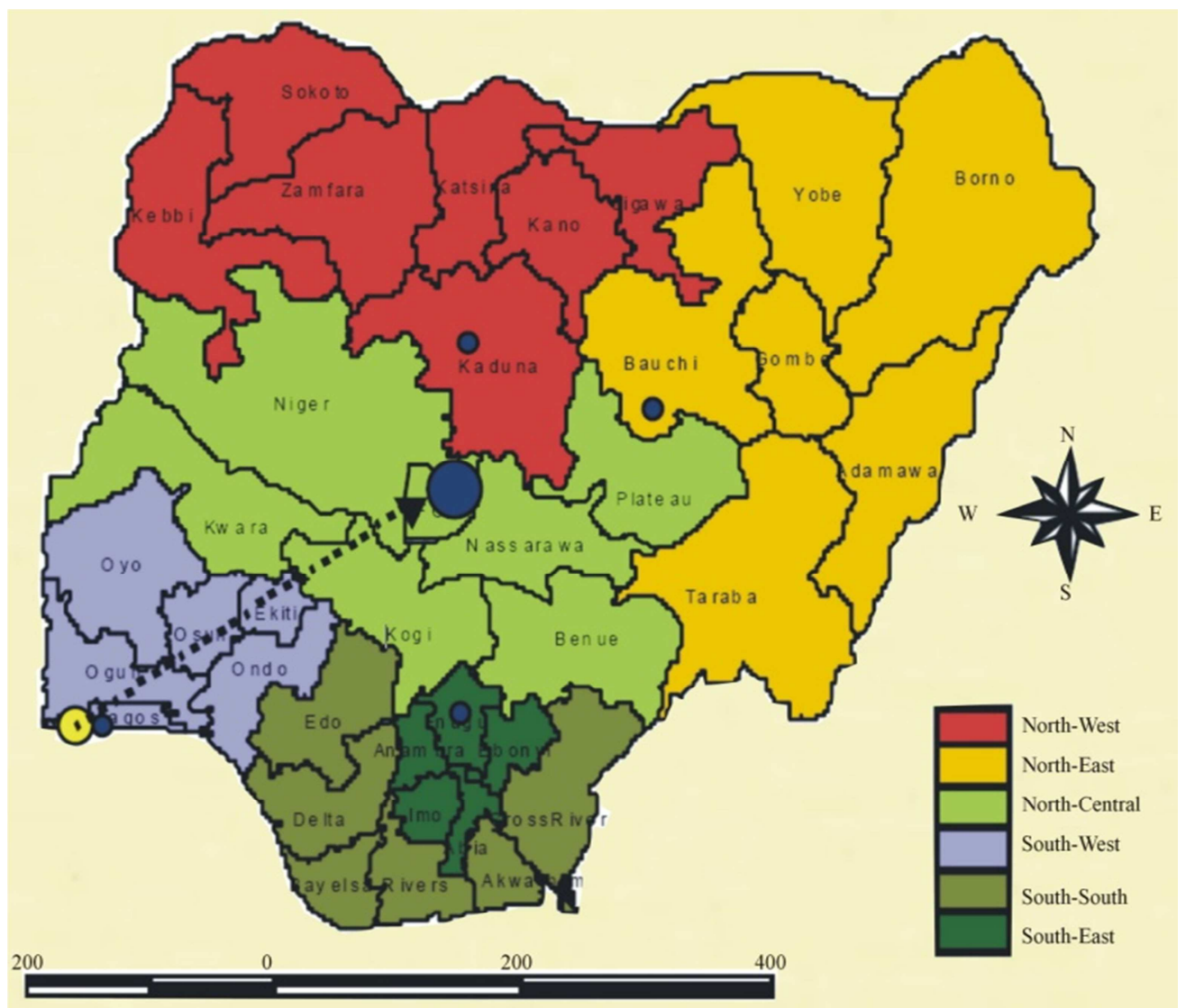

Figure 2. Map of Nigeria showing States. 


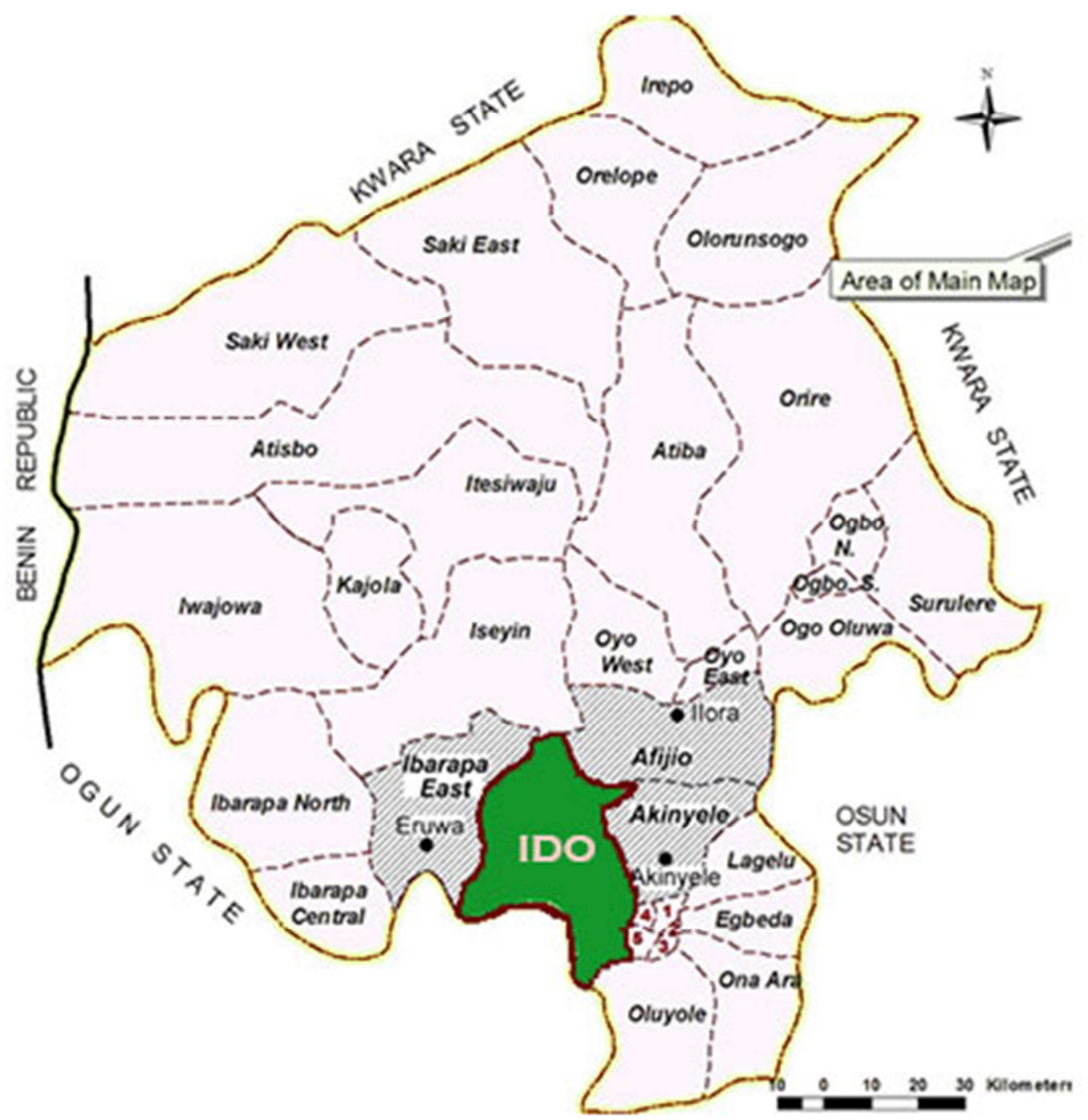

Figure 3. Map of Oyo State showing the Local Government Areas.

Sources of maps

Map 1: www.metrobusmap.net/whereisnigeria

Map 2: mstbstoiclr.890.com

Map 3: kingstartechsupports.com

\subsection{Data Collection and Methods}

Data on past land-use patterns of Osho Forest Reserve were obtained from the Oyo State Ministry of Agriculture, Natural Resources and Rural Development through their periodic reports, working plans and expert knowledge from the Management. Also, map of the area showing the various compartments was obtained and later improved using Geographic Information System (GIS) in order to facilitate better resolution. The whole area of the Forest Reserve was traversed in order to observe some notable areas so as to authenticate data from the Management of the Reserve and those of satellite imageries showing the land-cover. All available data sources for Landsat satellite imageries covering the period 1975-2005 were evaluated. Only Landsat imageries were used so as to eliminate the need for image resampling. All the available ones were downloaded from the
US Geological Survey site at http://glovis.usgs.gov. However, some imageries could not be used for this study because of cloud cover. Therefore, imageries of 1984, 2000 and 2006 were used. The imageries contain good spectral information on the study area and were therefore used to assess the patterns of land-use and land-cover changes.

All the satellite imageries used for the study were georeferenced to the same coordinate system using the topographical map of the area obtained from the Management of the Forest Reserve. Identification of key features on the image data (also visible on the topographical map) was a key factor in image georeferencing. The intersections of streams and highways (many of the highways have not changed over time) were used as ground control points. These were also used to delineate the map of the study area from the large imageries; in order to exclude areas that are not part of the Forest Reserve. In other words, the 
map of the Forest Reserve at inception which had been improved by GIS to facilitate better resolution was digitized using ArcGIS 8.1 and this was used to delineate on the imageries by using it as mask to extract the study area from the much larger Landsat imageries. The newly delineated imageries were then used for the study as these ensured that further analyses on the imageries were confined to the boundaries of the study location. Bands 2, 4 and 5 with the least correlation and the most relevant for vegetation studies following [13] were adopted for this study using Idrisi32. The three selected bands were combined to give a composite image in Idrisi using the composite tool and this was done for all the imageries used for this study. The resultant image was a false colour 8 bit RGB image suitable for analysis. Based on this false colour, image classification was carried out. An unsupervised classification was initially carried-out to determine the natural vegetation clusters which the imageries contain but this gave many classifications most of which were identical.

Three major clusters were identified on further inspection and based on knowledge of the study area; these were found to correspond to Natural Forest (NF), Plantation and Farmland. After this, a supervised image classification was undertaken. The resultant images for all the years used were then queried using GIS data query to determine the land area enclosed by each land cover-type. This yielded data about each land cover-type and a simple analysis of the data variation showed the changes the land-cover types underwent over the timeframe used for this study. A land-cover map for each year for which imagery was available was then produced from the classification results. The maps provided a visual representation of the area enclosed by each land-use type and a clear representation of the nature and spatial extent of the change.

\section{Results}

\subsection{Land-Use and Land-Cover Changes in Osho Forest Reserve}

Figures 4, 5 and 6 show the maps derived from landsat imageries of Osho Forest Reserve in 1984, 2000 and 2006 respectively. Table 1 shows the result of land-cover (LC) distribution for Osho Forest Reserve over the study period. In 1984, NF had a very high percentage area of $93.8 \%$ while Farmland had the least percentage area of less than $1 \%$ $(0.2 \%)$ whereas Plantation had a percentage of $6.0 \%$. Farmland had the highest percentage area of $57.3 \%$ followed by NF with $29.8 \%$ while Plantation had a value of $13.0 \%$ in year 2000. The results in 2006 are similar to those of 2000 with Farmland still having the highest percentage of $87.0 \%$ while Plantation and NF had $9.0 \%$ and $4.0 \%$ respectively. Overall, Farmland increased drastically during the study period whereas NF decreased while Plantation did not follow any definite trend; although it initially increased between 1984 and 2000 but decreased between 2000 and 2006 .

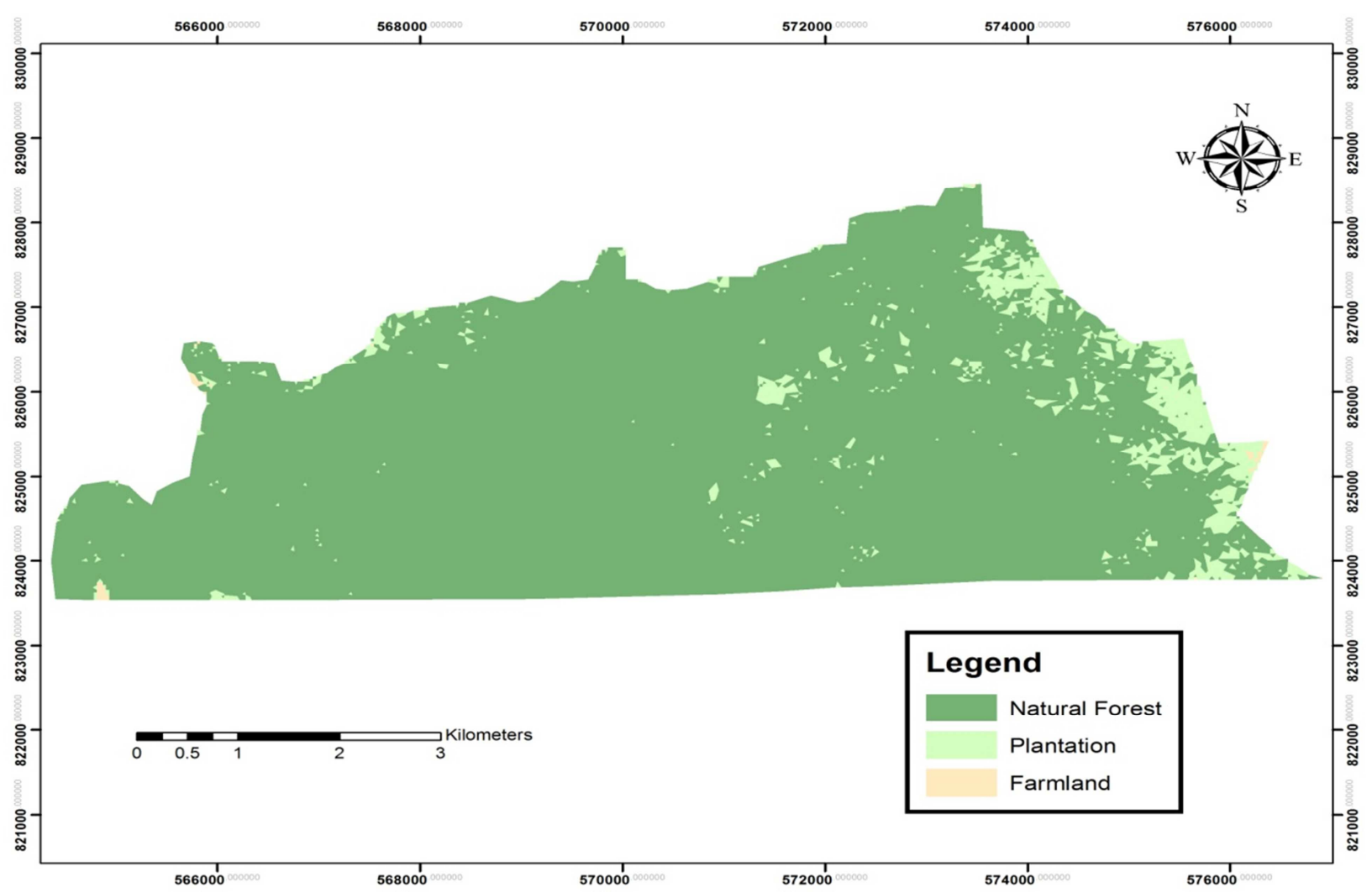

Figure 4. Land-Cover Map of Osho Derived from Landsat Imagery of 1984. 


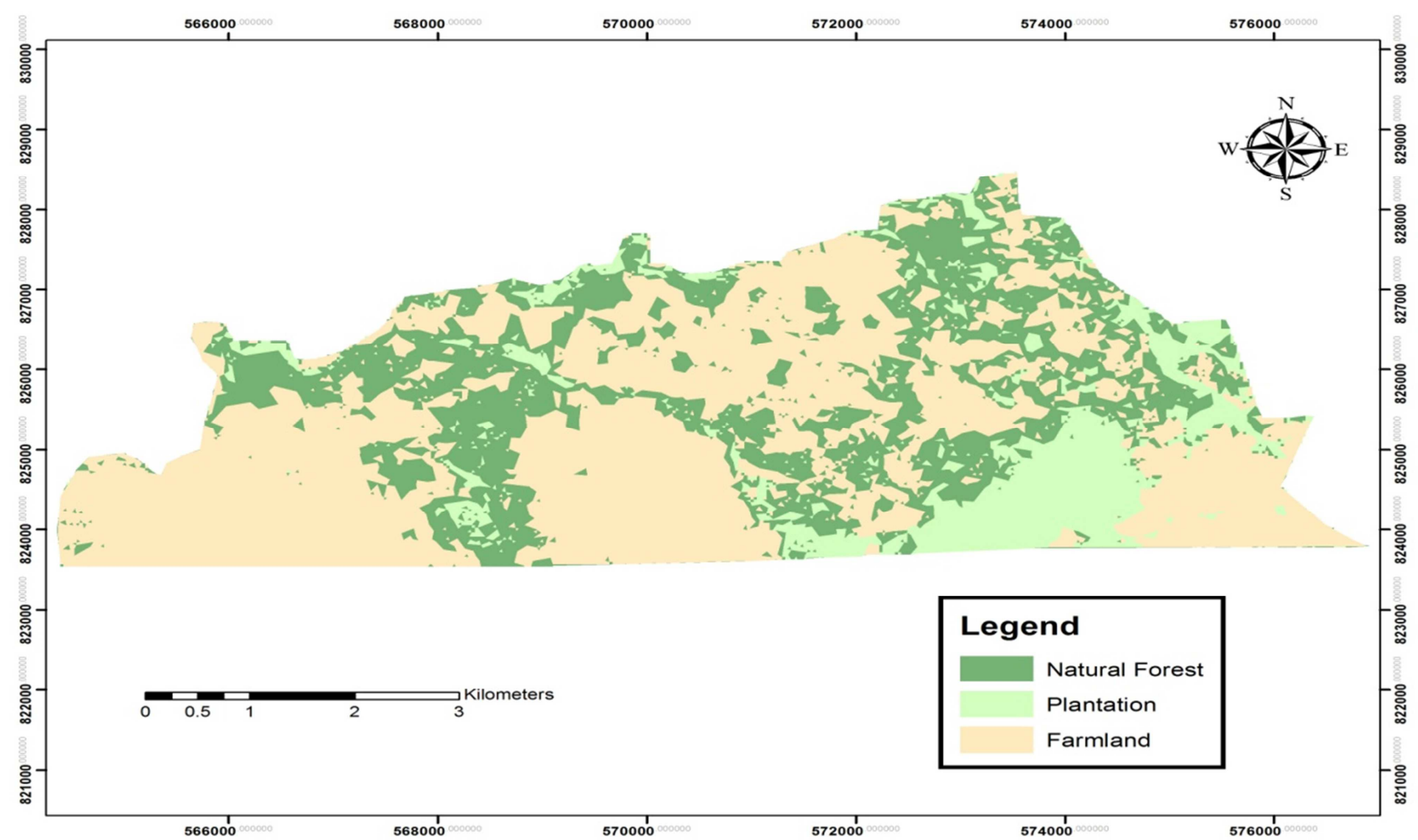

Figure 5. Land-Cover Map of Osho Derived from Landsat Imagery of 2000.

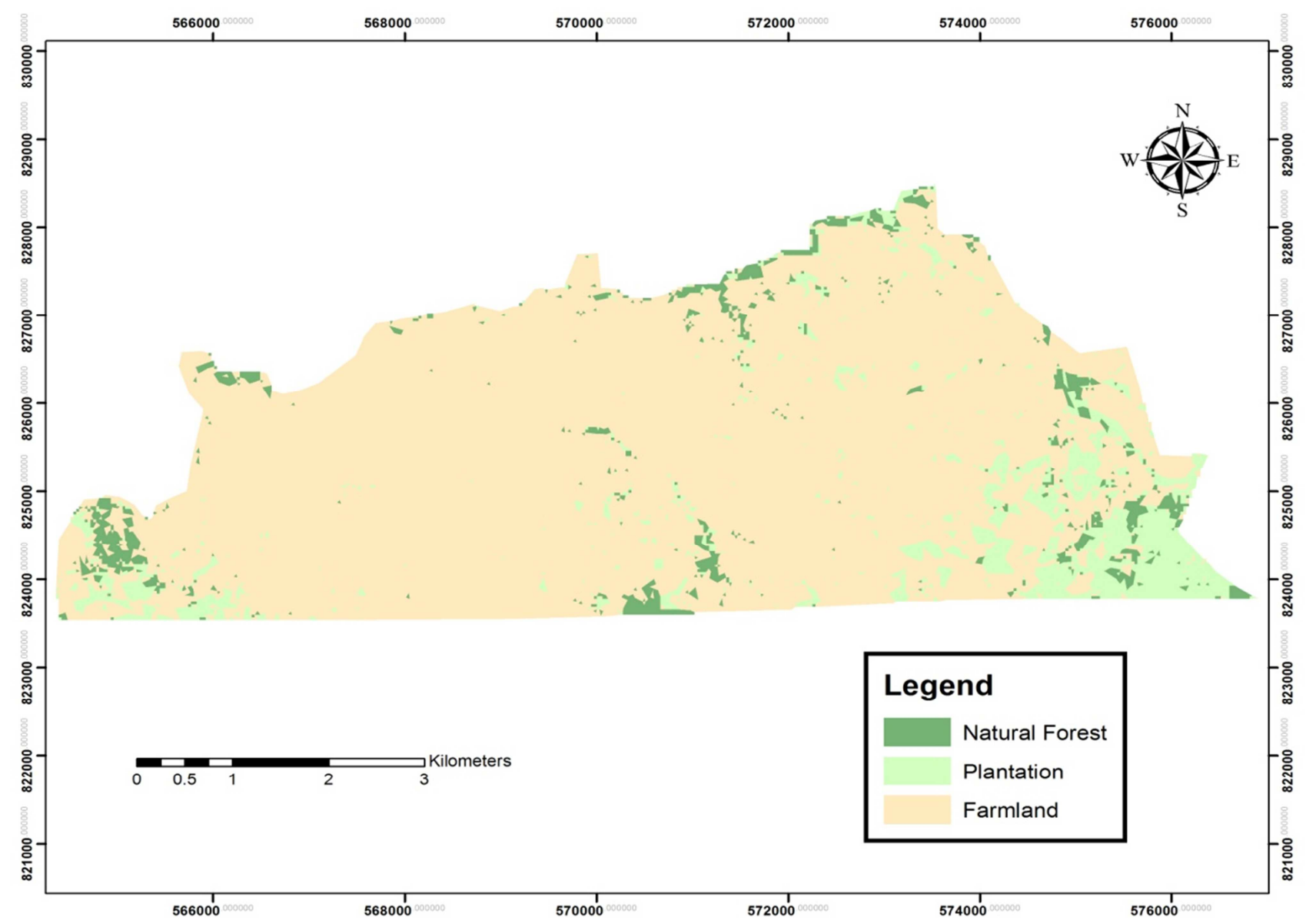

Figure 6. Land-Cover Map of Osho Derived from Landsat Imagery of 2006. 


\subsection{Net Change in Osho Forest Reserve Between 1984 and 2006}

Analysis of net change within each land-cover category showed that great decrease in extent occurred in NF with a percentage net change value of $-95.7 \%$, this signified that NF shrank in extent between 1984 and 2006. However, the greatest expansion was observed in Farmland with a value of $54.8 \%$ closely followed by that of Plantation with a value of $50.0 \%$ (Table 2).

Table 1. Land-cover Distribution for Osho Forest Reserve in 1984, 2000 and 2006.

\begin{tabular}{|c|c|c|c|c|c|c|}
\hline \multirow{2}{*}{$\begin{array}{l}\text { Land-cover } \\
\text { category }\end{array}$} & \multicolumn{2}{|l|}{1984} & \multicolumn{2}{|l|}{2000} & \multicolumn{2}{|l|}{2006} \\
\hline & $\begin{array}{l}\text { Area } \\
(\text { Ha) }\end{array}$ & $\begin{array}{l}\text { Area } \\
(\%)\end{array}$ & $\begin{array}{l}\text { Area } \\
\text { (Ha) }\end{array}$ & $\begin{array}{l}\text { Area } \\
(\%)\end{array}$ & $\begin{array}{l}\text { Area } \\
(\mathrm{Ha})\end{array}$ & $\begin{array}{l}\text { Area } \\
(\%)\end{array}$ \\
\hline $\begin{array}{l}\text { Natural } \\
\text { Forest }\end{array}$ & 3591.00 & 93.8 & 1138.73 & 29.8 & 153.14 & 4.0 \\
\hline Plantation & 229.66 & 6.0 & 496.72 & 13.0 & 344.55 & 9.0 \\
\hline Farmland & 6.06 & 0.2 & 2191.28 & 57.3 & 3329.03 & 87.0 \\
\hline Total & 3826.72 & 100 & 3826.72 & 100 & 3826.72 & 100 \\
\hline
\end{tabular}

Source: Author's analysis

Table 2. Net Change in Osho Forest Reserve between 1984 and 2006.

\begin{tabular}{llll}
\hline $\begin{array}{l}\text { Land-Cover } \\
\text { category }\end{array}$ & $\begin{array}{l}\text { Net Change } \\
\text { Area (ha) }\end{array}$ & $\begin{array}{l}\text { Area (\%) } \\
\text { Percentage Net } \\
\text { Change }\end{array}$ \\
\hline Natural Forest & -3437.85 & -89.8 & -95.74 \\
Plantation & 114.88 & 3.0 & 50.02 \\
Farmland & 3322.97 & 86.8 & 54.80 \\
\hline
\end{tabular}

Source: Author's analysis.

\section{Discussion}

Land-Cover Changes in Osho Forest Reserve

The area occupied by NF in Osho Forest Reserve as at 1984 was the largest with a value slightly above $90 \%$ but by 2006 , this had reduced to less than $5 \%$. This must have resulted from excessive exploitation consequent upon poor management. As at the time the imageries of 2000 and 2006 were taken, the roads leading to the Reserve were very bad and this must have negatively affected proper monitoring of the activities in the reserve by Forest Guards and Superintendents. However, reverse is the case with respect to area occupied by Farmland in comparison with NF. In 1984, it had a value which was less than $0.2 \%$ but by 2006 , the area had increased to about $90 \%$. Osho Forest Reserve was once referred to as a rain forest [14] but due to serious depletion of its resources, it has become a derived savanna. This might not have been unconnected with annual fires usually inflicted on such a forest in search of bushmeat and for ground preparation for farming especially during dry season and at the onset of rainy season. It has been said concerning tropical forests that fires lead to degradation of the forest towards xerophytic and pyrophytic plant communities dominated by grasses and fire-tolerant trees and shrubs [15]. Hardly could a big standing tree of indigenous species be found except in very difficult terrains where wood extraction is very difficult especially areas that are very close to river banks and where the river overflows its banks particularly during rainy season as well as areas that harbour dangerous wild animals. The whole reserve appeared more like an agricultural land with many agronomic crops being raised there ranging from grains to tubers. The reserve must have been stocked with matured indigenous trees in times past as gathered from the Forest Guards and rural people from communities close to the reserve who were of the opinion that the reserve had been degraded. One obvious reason for this degradation must have been wood extraction without sufficient effort to carry out reforestation and since not all indigenous species coppice; the whole location looked more like a farmland/grassland. [16] indicated that landuse and land-cover changes are local and place specific, occurring incrementally in ways that often escape our attention. Also, [17] observed that population growth among the communities around the forest imposes a lot of pressure on the forest for subsistence farming.

Attempt was being made by the Forestry Department, Oyo State Ministry of Agriculture, Natural Resources and Rural Development to carry out reforestation of the reserve mainly through taungya (agrisilviculture) practice. This must have resulted in the gradual increase in the area occupied by Plantation between 1984 and 2000. This age-long practice was gradually yielding good results. Eight of the communities close to the Forest Reserve were involved in the taungya practice and these were Adedapo, Agbetu, Gbagba, Abokede, Bolorunpelu, Araromi, Onikanga and Onifufu. The Ministry in collaboration with community leaders engaged interested farmers from these communities in this practice by allocating plots of land within the reserve to farmers for planting agronomic crops of their choice while they also nurture forest tree seedlings supplied by the State Ministry. Apart from the Forestry Trust Fund that was used to raise twenty-five hectares of Tectona grandis and Gmelina arborea in 1997; and fifteen hectares of the same species in 1998, the main means of regenerating the reserve was achieved by taungya. The Zonal Forestry Office ensured that these farmers adhered strictly to raising young trees of both Teak and Gmelina. One remarkable observation was that the floor of Gmelina plantation was very clean and devoid of irregularly emerging stems. This was because the taungya farmers lifted wildlings from under the mother trees and used them as planting stocks in new plots to be reforested thereby giving an impression as if serious silvicultural operations such as thinning and cleaning were undertaken in the Gmelina plantation. Moreover, both teak and Gmelina plantations in the reserve had not been harvested except in a few places where illegal felling took place, this explains the decrease of $3 \%$ in area occupied by Plantation between 2000 and 2006.

A key observation in this study is the declining natural forest extent and expansion of farmland. This result is similar to that of [18] where they also attributed mode of incursion into Oluwa forest reserve (a forest reserve in Southwestern Nigeria) to agroforestry and arable cropland. The result of this study is also in line with the view of [19] that most of the tropical forests cleared each year are due to agricultural practices. Similarly, it also supports [20] who reported that 
deforestation is largely due to intensification of agriculture involving clearing of forests in order to plant crops.

Furthermore, the use of satellite imageries in this study which can give much larger view of the earth's surface features than aerial photographs is an improvement over [21] who assessed deforestation in a lowland forest area of Southwestern Nigeria with the use of aerial photographs. Contrary to the statement of Adeofun (1991) that most forest conversion activities occur outside the Forest Reserves, forest conversion within Forest Reserves was observed in this study. The contrast might have been due to complete extraction of useful species outside the Forest Reserves thereby leading to encroachment of the supposed reserved areas in search of forest resources not minding the cost. As at the time of field work in the study location, the Forest Reserves in Oyo State, Southwestern Nigeria that harbours the study area were supposed to be closed to logging activity yet logging activity was observed with the sound of power saw at work to the amazement of accompanied forest guards. This observation still highlights the need for better actions in the conservation of Forest Reserves generally in Nigeria.

\section{Conclusion}

Results of this study have shown that there had been serious degradation of the resources in the forest reserve. As earlier reported, only patches of natural forest were left in the study location. If deforestation and forest degradation continue in this location unabated, then the future of the reserve would be threatened with nothing remaining in terms of trees along with an indiscriminate loss of biodiversity and forest services such as windbreak, erosion control, watershed protection and climate mitigation. Moreover, the forest reserve that should serve as carbon sink for $\mathrm{CO}_{2}$ emissions from other sources thereby maintaining ecological balance and preventing global warming would rather become carbon source. Forests should not only be valued for timber but also for their numerous ecological and social services, some of which may not be quantifiable in monetary terms.

\section{Recommendations}

The management of the Forest Reserve should set machinery in motion to forestall negative land-uses as this will curb the resultant adverse effect. Also, studies of this type should be carried out periodically using more recent satellite imageries to know the status of the Forest Reserve per time. Public awareness of proper use of the forest to aid sustainability of its goods and services should be done regularly using various media.

\section{References}

[1] Barnsley, I. 2008, Reducing emissions from deforestation and forest degradation in developing countries (REDD): A guide for indigenous peoples. United Nations University, Institute of Advanced Studies, Yokohama 220-8502, Japan.
[2] Rodgers, W. A. Patterns of loss of forestry biodiversity- a global Perspective. In Proceedings of the XI World Forestry Congress, Antalya, Turkey. 13-22 October 1997. Volume 2, Topic 7.

[3] FAO. Global Forest Resources Assessment 2005, Rome, Italy.

[4] Cottorone, D. Ed. Communal forest ownership: An option to address the underlying causes of deforestation and forest degradation in Ethiopia. Proceedings of a workshop. November 25-27, 2008. Published by Melca Mahiber.

[5] Anderson, J. R., Hardy, E. E., Roach, J. T., and Witmer, R. E., 1976, A land-use and land-cover classification system for use with remote sensor data. Geological Survey Professional Paper 964. Converted to Digital in 2001.

[6] Zhao, S., Liu, S., Li, Z., and Sohl, T. L., 2009, A spatial resolution threshold of land-cover in estimating regional terrestrial carbon sequestration. Biogeosciences Discussions, 6, 7983-8006. www.biogeosciences-discuss.net/6/7983/2009/.

[7] Charnley, S., Fischer, A. P., and Jones, E. T., 2007. Integrating traditional and local ecological knowledge into forest biodiversity conservation in the Pacific Northwest. Forest Ecology and Management, 246 (1), 14-28.

[8] Ford, D. N., and Sterman, J. D., 1998, Expert knowledge elicitation to improve formal and mental models. System Dynamic Review, 14 (4), 309-340.

[9] Meyer, M. A., and Booker, J. M., 2001, Eliciting and analyzing expert judgment: a practical guide. Philadelphia: Society for Industrial and Applied Mathematics.

[10] Chalmers, N., and Fabricius, C., 2007, Expert and generalist local knowledge about land-cover change on South Africa's Wild Coast: Can local ecological knowledge add value to science? Ecology and Society, 12 (1), 10. www.ecologyandsociety.org/vol12/iss/art10 [accessed 26.10.18].

[11] Drescher, M., and Perera, A. H., 2010, Comparing two sets of forest cover change knowledge used in forest landscape management planning. Journal of Environmental Planning and Management, 53 (5), 591-613.

[12] Pullin, A., Knight, T., Stone, D., and Charman, K., 2004, Do conservation managers use scientific evidence to support their decision making? Biological Conservation, 119 (2), 245-252.

[13] Salami, A. T., 1999, Vegetation dynamics on the fringes of lowland humid tropical rainforest of southwestern Nigeria- an assessment of environmental change with air photos and Landsat TM. International Journal of Remote Sensing, 20 (6), 1169-1181.

[14] Olaleye, O. A., and Ameh, C. E., 1999, Forest Resource Situation Assessment of Nigeria. An EC-FAO Partnership Programme. Forest Resources Main Report (Draft). Volume 11 .

[15] Goldammer, J. G., and Price, C., 1998, Potential impacts of climate change on fire regimes in the tropics based on Magicc and GISS GCM-derived lightning model. Climatic Change. $39,273-276$.

[16] De Sherbinin, A., Kline, K., and Raustiala, K., 2002. Remote sensing data: Valuable Support for Environmental Treaties. Environment, 44 (1), 20-31. 
[17] Salami, A. T., 2006, Monitoring Nigerian Forest with NigeriaSat-1 and other satellites. In Salami AT (ed), Imperatives of Space Technology for Sustainable Forest Management. Proceedings of an International Stakeholders' Workshop Sponsored by National Space Research and Development Agency (NASRDA), Abuja.

[18] Salami, A. T., Ekanade, O., and Oyinloye, R. O., 1999, Detection of forest reserve incursion in Southwestern Nigeria from a combination of multi-date aerial photographs and high resolution satellite imagery. International Journal of Remote Sensing, 20 (8), 1487-1497.
[19] World Bank. Forest sector policy paper. The World Bank, Washington, D. C. 1991.

[20] Bilsborrow, R. E., 1994, Population, development and deforestation: some recent evidence. In Population, Environment and Development, edited by the United Nations (New York: UN), 117-134.

[21] Adeofun, C. O., 1991, Assessment of deforestation in a lowland rain forest area of southwestern Nigeria using remote sensing techniques. PhD thesis, Department of Forest Resources Management, University of Ibadan, Ibadan, Nigeria. 1991, pp. 240+xxi. 